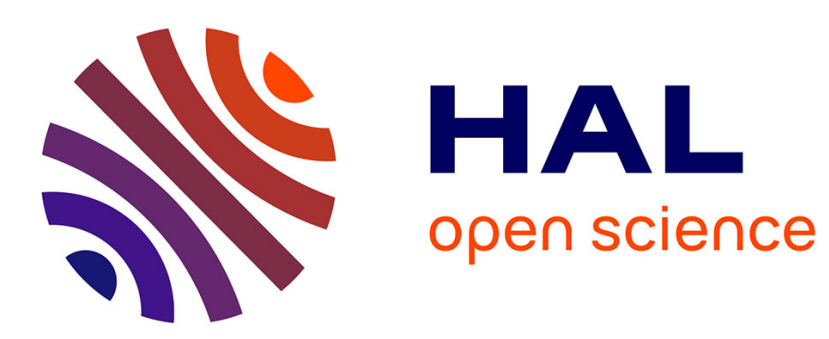

\title{
Toward a philosophy of technosciences
}

\author{
Bernadette Bensaude Vincent, Sacha Loeve
}

\section{To cite this version:}

Bernadette Bensaude Vincent, Sacha Loeve. Toward a philosophy of technosciences. Sacha Loeve; Xavier Guchet; Bernadette Bensaude-Vincent. French philosophy of technology : classical readings and contemporary approaches., 29, Springer, pp.169-186, 2018, Philosophy of engineering and technology, 978-3-319-89518-5. 10.1007/978-3-319-89518-5_11. hal-01820186v2

\section{HAL Id: hal-01820186 \\ https://hal.science/hal-01820186v2}

Submitted on 17 Aug 2018

HAL is a multi-disciplinary open access archive for the deposit and dissemination of scientific research documents, whether they are published or not. The documents may come from teaching and research institutions in France or abroad, or from public or private research centers.
L'archive ouverte pluridisciplinaire HAL, est destinée au dépôt et à la diffusion de documents scientifiques de niveau recherche, publiés ou non, émanant des établissements d'enseignement et de recherche français ou étrangers, des laboratoires publics ou privés. 


\title{
Toward a Philosophy of Technosciences
}

\author{
Bernadette Bensaude Vincent \\ Centre d'Etude des Connaissances, des Techniques et des Pratiques (CETCOPRA) \\ Université Paris 1 Panthéon - Sorbonne, France
}

Sacha Loeve

Institut de Recherches Philosophiques de Lyon (IRPhiL)

Université Jean Moulin Lyon 3, France

\begin{abstract}
The term "technoscience" gained philosophical significance in the 1970s but it aroused ambivalent views. On the one hand, several scholars have used it to shed light on specific features of recent scientific research, especially with regard to emerging technologies that blur boundaries (such as natural/artificial, machine/living being, knowing/making and so on); on the other hand, as a matter of fact "technoscience" did not prompt great interest among philosophers. In the French area, a depreciative meaning prevails: "technoscience" means the contamination of science by management and capitalism. Some even argue that "technoscience" is not a concept at all, just a buzzword. In this chapter, on the contrary, we make the case for the constitution of a philosophical concept of technoscience based on the characterization of its objects in order to scrutinize their epistemological, ontological, political and ethical dimensions.
\end{abstract}

Keywords: epistemology, ethics, design, history and philosophy of technoscience, objects, ontology, philosophy of technology, technoscience, science and technology studies, values in science and technology

\section{Introduction}

Technosciences have a bad reputation. Despite the inflation of the use of this term over the past decades - indicated by Google n-Gram viewer - it is neither a taxonomic category referring to a class of disciplines nor a well-defined concept. The compound term has been used as a qualifier ("technoscientific societies") in a course of public policy science as early as the 1960s (Caldwell and Deville 1968). However, as François-David Sebbah (2010) rightly noticed, it has never been appropriated by the actors of technoscientific research, who chose to label the research fields they initiated "materials science and engineering," "biotechnology" or "genetic engineering," rather than "molecular technoscience" or "biotechnoscience." Scientist, engineers, designers, science-policy makers, research managers are reluctant to use this term. Technoscience appears to be a practice without (explicit) practitioners.

While the term did not catch up among scientific communities, it did not raise greater enthusiasm among philosophers. Some of them are very critical: technoscience is just a distortion of pure science resulting from its contamination by ideology (Seris 1994; Bunge 2012) or a post-modernist buzzword (Raynaud 2016). Accordingly it would be better to forget about it and return to more serious topics! Even scholars in Science and Technology Studies (STS) and philosophers of science who are more engaged with actual scientific practices do not care for a distinction between science and technoscience, since technical intervention is a necessary condition of all knowledge production in modern science. The close interaction 
between science and technology, between representing and intervening in Ian Hacking's terms (1983) is a major feature of all scientific practice. So there is no need for a special philosophical investigation of technosciences.

This chapter takes the concept of technoscience seriously and makes the case for the relevance and legitimacy of a philosophy of technoscience. It uses it as a philosophical tool for better understanding current trends in scientific research and shows how it can acquire a descriptive and analytic value despite and along with its polemic charge. Following a brief historical survey of the evolution of the notion of technoscience and its uses since its coinage, this chapter will outline three profiles of technoscience, (i) epistemological, (ii) ontological, (iii) politico-ethical. These three ways of "portraying" technoscience highlight some of its major, albeit nonexclusive and non-exhaustive, philosophical characteristics:

(i) a way of knowing through making, which can be seen as a further development of Ian Hacking's characterization of laboratory style in a "design" mode;

(ii) a specific mode of existence of objects which commands a shift from epistemic pluralism to ontological pluralism;

(iii) an intrinsic value-ladenness which requires shifting our views of objects from ethical neutrality to ethical ambiguity.

\section{Genealogy of a concept}

The term "technoscience" has been coined by Belgian philosopher Gilbert Hottois to initiate a philosophical program in the 1980s. Undoubtedly, the term had been in use long before. As French philosopher Dominique Raynaud carefully highlighted (Raynaud 2016), "technoscience" came out in the immediate post-war period and appears occasionally for over two decades in literature related to science policy (Laswell 1946, 1948, 1957; Roherty 1960), or to environmental issues (Rudd 1964; Clement1965), especially in the North American era. Hottois has thus no paternity stricto sensu on the word "technoscience." However, he certainly was the first to provide the concept of "technoscience" with high philosophical significance and impact.

He first used the compound term "techno-science" as a provocative phrase for waking up philosophers from their "linguistic slumber" (Hottois 1979). Hottois deplored that both analytic and hermeneutic philosophers had relinquished the handling of reality to the techno-sciences. By seeking refuge in a "metalinguistic," they condemned philosophy to a condition of "secondarity." Consequently, Hottois initiated a philosophy of "technoscience" (without hyphen), focused on the contemporary practices of science characterized by a new regime of research in which technology becomes the milieu, the driver and the finality of research (Hottois 1984). Technoscience thus referred to the reciprocal process of internalization of science into technè and of technè into science. This concept is close to Don Idhe's views on instrumental materiality developed in Instrumental Realism: The Interface between Philosophy of Science and Philosophy of Technology (Idhe 1991).

However, as Hottois's Chap. 8 in this volume clearly demonstrates, this genealogy of technoscience is only part of the story because of the close association of this notion with postmodernism, initiated by Jean-François Lyotard who popularized the term "postmodern." In La condition postmoderne. Rapport sur le savoir (1979), Lyotard reflected on the status of knowledge in postindustrial and computerized societies. Two major features struck him: technoscience is ruled by the norms of performativity (see Sebbah, Chap. 10 in this volume) and it demises the 
grand narratives (grands récits). He argued that the traditional relationship between science and technology was reversed. Technology was taking the lead in scientific research. As knowledge and power became two sides of the same coin, postmodern culture could be characterized by the collapse of the modern ideal of emancipatory science. Technoscience thus mainly referred to a reversal of the values between science and technology, which marks an epochal break (Forman 2007).

In the context of early STS, Bruno Latour gave technoscience a quite different meaning. He used "the word technoscience to describe all the elements tied to the scientific contents no matter how dirty, unexpected or foreign they seem, and the expression 'science and technology', in quotation marks, to designate what is kept of technoscienceonce all the trials of responsibility have been settled." (Latour 1987: $174)^{1}$ In analyzing the construction of both scientific facts and technological objects along the networks of a multitude of heterogeneous actors, Latour claimed to uncover the complex alliances between human and non-human actors, nature and society, that are usually obfuscated by the work of "purification" of scientific facts. Contrarily to Hottois or Lyotard, Latour did not refer technoscience to a new epoch of research. It is nothing but "science in the making": The true expression of the real, impure and mixed practices of the sciences as they are made. Accordingly, science has always been technoscience, and today's explicitly impure technosciences - such as nanotechnology or synthetic biology - are nothing more than the "speaking-truth" of science, the sign that we are ceasing to believe that we have once been "modern."

Donna Haraway (1997) embodied technoscience in her famous figure of the cyborg, which combines biological processes with social and cultural patterns, thus making an actual mixture of heterogeneous components that challenges all attempts at purification. Just like the phrase "cyborg" results from the agglutination of the two incompatible notions of "cybernetic machine" and "biological organism," in her prose, "technoscience" expresses one of the "wobbly couplings" of the contemporary condition (nondualistic, nonmonistic), and it is the same for naturecultures, oncomouse, and FemaleMan. Haraway added to the notion of technoscience a heavy load of irony and blasphemy as she incorporated it in the corpus of feminist and postmodernist literature. When she moved from the figure of the cyborg to domesticated dogs, she added to the notion of impurity that of mutual invention (Haraway 2003). Just as dogs and humans invent each other, every one shapes her identity through interactions with otherness.

The tremendous success of feminist and postmodernist studies jeopardized further philosophical investigations of technoscience. ${ }^{2}$ Hottois himself switched to bioethics when he realized that the phrase "technoscience" had become a fashionable term widely used to refer to a vague entanglement of science, utilitarianism and capitalism (Hottois 1996), where he couldn't recognize his own notion. Don Idhe, by contrast, organized a seminar at Stony Brook University on technoscientific research in an attempt to engage a dialogue between the various perspectives on technoscience. Interesting comparisons came out of this attempt at "chasing technoscience." (Don Idhe 2003) A single common feature emerged from the panorama sketched in this volume: all contributors shared a concern with the materiality of scientific or human practices in general. On this basis, however, it

\footnotetext{
${ }^{1}$ One may notice that this use of "technoscience" makes of the label STS ("Science and Technology Studies") a misnomer!

${ }^{2}$ According to a bibliometric study based on a Google N-gram enquiry (Raynaud 2015) 41.69\% of the citations using the phrase "technoscience" refer to Donna Haraway's, Modest_Witness@Second_ Millenium. FemaleMan@_Meets_OncoMouse ${ }^{\mathrm{TM}}$ : Feminism and Technoscience (Haraway 1997).
} 
seems difficult to design a common research agenda in order to prevent the dissolution of technoscience in a vague postmodernist rhetoric.

The emergence of nanotechnology and converging technologies (NBIC for nano-bio-info-cogno technologies) in the 2000s prompted a renewed interest in technosciences among philosophers (Bensaude Vincent 2009; Sebbah 2010; Nordmann 2010; Guchet 2011; Dupuy, Chap. 9 in this volume). ${ }^{3}$ These ambitious programs were associated with national funding initiatives all over the world and gave rise to an entire economy of promises and fears. They attracted attention to a regime of production of science in which research is conducted in a context of application (Carrier and Nordmann 2010), where the setting of research priorities mimics the dynamics of markets while the production of knowledge mimics the industrial production of commodities (Pestre 2003). Yet this current regime of research deeply affects the status of knowledge. While it is now dominant, this regime of research is, however, not new. As a category referring to a style of research characterized by the sociotechnical shaping and production of scientific objects, technoscience can well be traced back at least to eighteenth-century chemistry (Klein 2005). The notion of technoscience may help disentangle the epistemological implications of such research practices provided it is viewed as an idealtype rather than as a new paradigm or an epochal break (Nordmann et al. 2011).

Going beyond the "nothing new" statement (science has always been technoscience) and the too historically simplistic claim of an epochal break was one of the objectives of the French-German project GOTO, "The Genesis and Ontology of Technoscientific Objects" (2010-2014). ${ }^{4}$ Far from claiming that all science could be exposed as technoscience, this research project was based on the assumption that one can clarify the distinction between science and technoscience by shifting the attention from the subjects to the objects of knowledge and clarifying their ontology. Scientific ontologies are typically made of facts, laws, and causal dispositions; they orient the cognitive practice towards the acquisition of a kind of knowledge that takes form of propositions, theories, hypotheses, models, explanations, representations, or predictions that areabout the world. ${ }^{5}$ By contrast, technoscientific research seeks to establish demonstrable capacities of construction and control by functionalizing objects, implementing new capacities and enhancing their value. Far from denying any difference between science and technology, the investigators of the project argued that while science and technology are two distinct albeit interacting spheres in the idealtype of "science," they are indistinguishable in the idealtype of "technoscience." Far for declaring the work of scientific "purification" of facts futile and meaningless, they argued that a technoscientific object is encountered when such purification proves impossible or unnecessary (Bensaude Vincent et al. 2011). The project invited philosophers, STS and historians to engage with these questions not only in order to appreciate the difference between science and technoscience, but also to draw their attention toward the modes of existence of research objects (Bensaude Vincent et al. 2017).

\footnotetext{
${ }^{3}$ Recently a comprehensive and epistemologically informed history of technoscience has been published by David F. Channel (2017). He argues that the roots of technoscience can be traced to the nineteenth and early twentieth centuries in chemical industry, electrical lighting, and telephone and radio research.

${ }^{4}$ The GOTO program, funded jointly by ANR (France) and DFG (Germany), gathered Bernadette Bensaude Vincent and Sacha Loeve in France together with Alfred Nordmann and Astrid Schwarz in Germany.

${ }^{5}$ Of course, from the epistemological perspective of instrumentalism, scientific representation does not reach an unobservable mind-independent reality, but it makes it observable if one carries out certain actions.
} 


\section{Epistemological profile: Research in a design mode}

If intervening rather than representing the world, captures the epistemological credo of Nancy Cartwright and Ian Hacking, then technoscientific research could bring grist to the mill of the so-called "Stanford School of philosophy." Hacking convincingly argued that laboratory experimentations were not just a way to control postulation through observation and measurement and to represent nature. Cartwright (1999) emphasized the virtues and limitations of the experimental settings specifically constructed by physicists or economists to fit in their theoretical models and providing some understanding and control of phenomena. "Nomological machines" - as she named these arrangements used to capture regularities and formulate laws - are suited to serve cognitive and predictive functions but as they provide an idealized picture, they are not robust enough to encounter the real world.

Technoscientific research is full of machines - electronic devices, sensors, actuators, microscopes, molecular machines - but they are not used as typical scientific instruments. They are not used to test hypotheses, to control postulation through observation and measurement and to represent nature. They rather belong to a specific style of laboratory experiments aimed at manipulating objects (Hacking 1983). They do not operate as Cartwright's "nomological machines" revealing regularities and laws. They are enabling machines, or tools to make something. They violate the scientific imperative of distance to secure objectivity. For instance, the scanning tunneling microscope (STM), the icon of nanotechnology research, challenges the epistemic gospel of modern science. First, the STM and other related techniques of near-field microscopy, which approach the object as closely as possible in order to pick-up the information at the surface of the sample, induce a "collapse of distance" (Nordmann 2006). Moreover, the STM is as much an instrument of observation as an apparatus of manipulation. It is not just because, as Hacking argued, there is no visualization without intervention. The STM does not visualize but probes the atomic surface with its tip in a kind of machinic "touch." It even connects itself to a molecular adsorbate. It does not just scan the structure under the tip. It actually constructs new structures through its intervention. The STM is both an instrument and a tool for designing new materials and machines (Nordmann 2010; Loeve 2011a).

Technoscientific research is mainly oriented toward design. "Redesigning life" or "shaping the world atom by atom," the slogans of synthetic biology and nanotechnology initiatives suggest that everything, from molecules to organisms can be designed (see Loeve, Chap. 22 this volume). "Materials by design," i.e. materials intentionally built up for specific purposes and for performing specific tasks are the core-model of materials research. With the mass diffusion of composite materials in automotive industry, aeronautics and sport articles, materials ceased to be the precondition for technological projects. Materials Science and Engineering subverted the linear model of innovation - from basic science to applied science to industry and market - and developed a systems approach with close collaborations between a variety of scientists and engineers (Bensaude Vincent 2001).

The view that materials were no longer a constraint has been reinforced in the 2000 s by the notion of "bottom-up design" spread in nanotechnology initiatives.

\footnotetext{
6 "Design" is such a fashionable term that is also prevails in STS. Significantly, design was the thematic topic of the 2012 joint meeting of the $4 \mathrm{~S}$ and the European Association for the Study of Science and Technology (EASST) with 1600 papers.
} 
Designing functional objects and organisms is the major achievement in technoscience. As the focus of research shifts from the correlation between structures and properties to performances and process, the object of design is no longer a sample representing general phenomena or a theoretical model embodied in matter. It is a thing with an intrinsic value, an end in itself rather than a means toward an end. In this context, atoms and molecules, genes and genomes, which were once considered as the basic constituents of matter and living beings, are reconceptualized as devices to make nanomotors, nanocars, nano-wheelbarrows, etc. Similarly, yeasts, bacteria, viruses are being reprogrammed, re-engineered, or redesigned to perform a number of tasks such as synthesizing therapeutic molecules, biofuels, or decontaminating toxic sites.

Does it mean that science would be sacrificed on the altar of technological innovations and utilitarianism? Actually, technoscientific researchers are often content to publish proofs-of-principles. By constructing a biological device or a molecular machine in the well-controlled conditions of the laboratory, they aim to show that such technology is possible. Such a proof manifests a capacity and opens up a possible future, but the effective realization of this possible is not a matter of concern in technoscientific research (Nordmann 2006), which in this regard cannot be confounded with applicative research. From the perspective of applied science or "pure engineering," a proof-of-principle is only a temporary and limited result that calls for further research and development efforts in order to be scaled-up. From the perspective of technoscience, it is genuine and valuable knowledge-production, knowledge about the possible rather than about the actual. Thus, that technoscience is not "pure science" does not mean that it is "pure engineering," nor that it is simply an "impure" hybrid of science and engineering.

Behind the rhetoric of promises used by technoscientists in their search for funding sources, their research practices are actually driven by cognitive goals. "What I cannot create, I do not understand," this remark by theoretical physicist Richard Feynman has been used again and again by synthetic biologists to describe their endeavor. Through making synthetic chromosomes or metabolic circuits, they seek knowledge about the fundamental workings of life, or possible life - extent life being often considered too "provincial" (i.e. too particular) by synthetic biologists to support fundamental biological knowledge (Attwater and Holliger 2014). For instance, the construction of minimal cells is explicitly aimed at two intermingled objectives: tackling the fundamental question of the origin of life and providing a standard "chassis" on which various functionalities can be implemented for predictably delivering specific performances on demand. Similarly, micro-machines are designed on the model of cell motility for the dual purpose of better understanding the complex behavior of living cells and guiding tiny robots within the body for diagnostic or therapeutic actions. To design such micro-robots researchers do not hesitate to practice a reverse engineering of natural cells in order to extract information about their behavior and design their machines on the basis of this information (Arroyo et al. 2012).

Within this epistemological framework where knowing and making are intermingled, nature itself comes to be viewed as a designer, whether it be an insuperable engineer (Jones 2004) or an awkward tinkerer whose work needs to be superseded (Endy 2005; Marliere 2009). This view is underlying the boom of biomimetic strategies in chemical industries and robotics where research programs on soft machines and soft robots are conducted. A remarkable example is plant robotics, aimed at growing plant-like robots compliant to environment. In a program 
inspired by plant roots, roots are viewed as "soft sensors \& actuators," with "distributed intelligence." Plant roots are a fascinating model because they are capable of odor detection without nose, breathing without lungs, movement without muscles, light perception without eyes, as well as of decision without brain, and communication without mouth (Mazzolai 2014). Through design practices, this technoscientific program results in disclosing nature's capacities rather than increasing our technological control over natural phenomena. As research in a design mode, technoscience is not necessarily meant at enhancing human performances or increasing our domination over nature. It is more adequately characterized as an exploration of nature's capacities, whereby nature is reconfigured as a field of possibilities.

To be sure, digital computation has fostered the ambitions of "rational design." Computational chemistry, for instance, is using the basic rules of physics and chemistry to model the behavior of potential compounds. Similarly, system biology aims to provide guidelines for synthetic biology by modeling genetic and metabolic circuits. The alleged complementarity between systems and synthetic biology relies on the dichotomy between theoretical hypotheses and experimental testing. At first glance, it thus seems that research in a design mode is enhancing the control of knowing over making, of basic science over technology. Computation based on the most fundamental information about atoms and genes dispenses with the cost of synthesizing thousands of molecules or genomes for selecting the one with desirable properties. "Now you can find out how well a new compound works before he does," claimed the advertisement of a corporation of molecular design (Chemical and Engineering News 1983: 19). The production of artifacts seems to proceed from the interaction between algorithms and the basic laws of physics and would just be the materialization of these products of the mind.

This view of design is favored by "star" technoscientists. For instance, biologist Craig Venter proudly advertised the success of his research group in transplanting a synthetic chromosome (a replica of the natural genome of Mycoplasma mycoides less 25\% "useless" genes) into another bacterial cell having its chromosome removed (Mycoplasma capricolum). The synthetic chromosome "takes control" over and "reprograms" the recipient cell, thus giving rise to a new species christened Mycoplasma laboratorium (Gibson et al. 2010). "This is the first selfreplicating cell we have had on the planet whose parent is a computer." (USA Today 2010) In thus emphasizing the role of the information embedded in genetic sequences, Venter obscured the huge efforts, technical skills and years of trials and errors that this prowess required from an army of human and nonhuman collaborators for inserting an entire genome in a cell and getting the cell to express it. First, the "artificial" synthesis of the chromosome required the help of other bacteria: the chemically synthesized DNA cassettes had to be assembled and cloned in Escherichia coli, and reworked in yeast. Second, processing DNA requires preexisting molecular machinery such as DNA and RNA polymerases for replication and transcription, ribosomes and other expression factors. These helper molecules are not synthesized de novo, they are extracted from preexisting living cells. Finally, the expression of the transplanted genome was possible only because the two species chosen as donor and recipient were close cousins belonging to the same genus Mycoplasma. Because DNA requires proteins to make proteins, two too distant species could not make it, as they would present incompatible binding sites and binding factors. The painstaking technical work and the know-how displayed by laboratory workers (including the helper bacteria) were systematically kept in the 
backstage in order to overemphasize the conceptual and abstract part of the process. The design is reduced to the model computed by bioinformatics while the actual production of the artifact is supposed to be no more than the execution of a program or the material projection of a conceptual pattern. The priority conferred to the abstract pattern over the process of concretization is clearly in keeping with the old hylemorphic model of art as the imposition of forms created by the mind (or a computer) upon a material substrate (Simondon 2016).

A closer glimpse on the actual practices of design in synthetic biology and nanotechnology laboratories conveys a quite different view. It provides a window on a range of experimental practices aimed at exploring the world as a field of potentials. On the basis of a number of famous examples of design in synthetic biology laboratories, Maureen O'Malley $(2009,2011)$ convincingly argued that the laboratory practices of synthetic biologists are not the materialization of computer models. She describes the experimental practices of synthetic biologists as an openended exploration of complex phenomena through the construction of objects. Far from being a straightforward and smooth process, such experimental investigations are made of "epistemic iterations" (Chang 2004), of gradual corrections of the wrong assumptions embedded in the design of the device. And at each step, they involve a lot of trials-and-errors, patching, hacking, debugging and kludging. ${ }^{7}$ In other terms, the image of rational design that the champions of synthetic biology have constructed is in stark contrast with the real skills that they have to mobilize to make do. In her conclusion O'Malley made an interesting suggestion:

The rhetoric of pure engineering appears to function as a strategy of discipline formation, which needs to be contrasted against the technical achievements (quite remarkable) and failings (less advertised) of synthetic biology so far. This question of whether kludging can be overcome or whether it lies inseparably at the heart of both life and biological practice is perhaps the general research question that synthetic biology is addressing (even if the "field" does not see it that way). (O’Malley 2009, 386)

The self-image of synthetic biologists as responsible engineers relying on sound and rational principles is at odds with their actual practice of astute and heterogeneous tinkering. In technoscientific research, failure is expected; failure is welcome, but not because it is perceived as the refutation of a conjecture or of a model. It is rather seen as an invitation to a rapprochement between the ways of nature and the ways of human technology. For instance, Michael Elowitz who pioneered the design of genetic circuits "from scratch" on the basis of two engineering principles - decoupling and abstraction - built a genetic circuit, an oscillator that was meant to operate as independently as possible from the underlying cellular system (Elowitz and Leibler 2000). However, the device did not work because noise and interaction with the host cell contributed to the process (Nandagopal and Elowitz 2011). Although the failure threatens the basic assumptions of biopart engineering, it has not been considered as a refutation that could threaten the promises of this approach to synthetic biology. The negative result has been turned into a new opportunity to explore the role of noise and stochasticity in living cells.

Here points the fascinating perspective of a process of mutual learning between the object and the subject of investigation. When looking at the actual practices of

\footnotetext{
${ }^{7}$ The phrase "kludging" coined in informatics and computer science, refers to an inelegant but successful solution to a problem in computer hardware or software. It is said to be an acronym made of three terms: klumsy, ugly and dumb.
} 
research in a design mode, it is clear that it is nothing like the projection of abstract engineering principles on a passive matter.

\section{Ontological profile: In the midst of things}

Let us turn now to the ontological assumptions underlying such research practices. Indeed ontology is not the major concern of technoscientific researchers. As mentioned above, they are not interested in representing the structure of matter, finding the ultimate particles, or even discovering the laws of nature. They are remarkably indifferent to the ontological structure of the world. As Peter Galison (2017) notices, the unconcern about ontological questions is a striking feature of current research, even in physics. Yet being indifferent to ontology does not mean being ontology-free.

One way of disentangling underlying ontological assumptions is by looking at the metaphors used by active scientists. In their discourses synthetic biologists use two favorite metaphors to describe what they are doing: assembling Lego ${ }^{\circledR}$ bricks into modules and reading and rewriting the code of life (Bensaude Vincent 2016). Both metaphors convey the view of intervention on passive material entities. Despite the popularity of the playful metaphor of the Lego ${ }^{\circledR}$ construction in the discourse of synthetic biologists, their practice is more like playing chess game with cells than assembling bricks to make a module. Listen for instance to Elise Cachat, a young scientist who is working on the design of mammalian cells in order to engineer tissues for kidney repair at Edinburgh University. She presents her work as "engineering self-organization in mammalian cells." (Cachat 2016) The title itself includes a paradox: if the cells are self-organized, the targeted arrangement proceeds from their own dispositions rather than from human intervention. Engineering in this case is not analogous to a design, with a designer informing matter and controlling its behavior. In a private interview Cachat acknowledges that she is uncomfortable with the term "chassis" borrowed from automotive industry, which suggests independent parts to be assembled along an assembly line. She says "my chassis often rebels. It is faster than me and responds before I can understand what's going on." In other terms, she plays and negotiates with the powers embedded in her object of design. Instead of looking at the object under scrutiny from a distance in order to objectify a phenomenon and control it, she operates in the middle of things, in medias res and strives to remain close to them.

While in the idealtype of "science" one always assumes a distance between knowing and being, technoscientific objects merge the epistemic and the ontological. Since scientific representations take the form of propositions, they assume that the world is composed of facts rather than of things or objects. Scientific propositions typically claim "that something is the case," (including dispositional properties), or that "this has been observed or measured," etc. By contrast, in the technoscientific model, the capacities of construction and control that objects demonstrate are not considered as confirmations or corroborations of propositions about them, but as knowledge in itself - "thing knowledge." (Baird 2004) ${ }^{8}$ It could well be argued from

\footnotetext{
${ }^{8}$ More materialistic than Latour, Baird criticizes both the semantic model of scientific knowledge as "justified true belief" and the semiologic model of the actor-network theory, with its text-producing blackboxes. Baird argues that scientific instruments do embed objective knowledge not so much because they are theory-laden (often they first function without a theory), but rather because of the analogy they draw between their technical functionning and the functional properties of truth. By studying the technicalities of instruments, Baird insists on "what truth does for us," assuming that the technical creation and stabilization of a new phenomenon is objective knowledge, even without theory or propositional knowledge. However,
} 
a technoscientific perspective that the kind of knowledge synthetic biology displays shifts the focus away from epistemic agents to objects as knowers, as Axel Gelfert (2013) put it. He provokingly but convincingly argued that the micro-organisms themselves could be considered as the loci of knowledge, of a "living thing knowledge," already stabilized in the form of sequences, proteins, organelles, and metabolic pathways that function well together, while synthetic biologists are clumsily attempting to access the working knowledge encapsulated in living organisms by reverse engineering.

Most technoscientific research presupposes the assumption of powers and agencies in molecules and living entities. In this respect, it is closer to Leibniz's monadology than to Descartes's mechanism. While the latter banned all powers and qualities from nature and compared it to a clock, the former understood the clock as a restless and responsive mechanism (Riskin 2015). Technoscience naturalizes agency rather than transferring all the powers and agencies to a designer. It is a way of exploring the capacities of a wide range of objects - molecules, nanoparticles, materials, genes, proteins, neurons, circuits, networks, etc - and taking advantage of their inner powers and spontaneous movements. It is seizing opportunities and trying to cooperate with what molecules can afford in certain circumstances or under specific constraints.

This focus on capacities rather than on the regularities of general laws suggests that a philosophy of technoscience could encourage the trend of Neo-Aristotelianism in philosophy supporting a realist perspective on causal powers (Greco and Groff 2013). While modern science equates nature and artifact and merges them in the universal mechanism, technosciences are rather sensitive to the local potentialities of matter. Far from being homogeneous and passive, materials have "implicit forms" (Simondon 2005) that offer a range of opportunities to scientists and engineers. As Simondon emphasized, technological design succeeds provided that it fits in with these local forms. Although technosciences operate according to scientific laws (quantum physics for instance remains the general framework in nanophysics), they are not interested in nomological work. They above all consist in taking advantage of local dispositions and powers that fix the spectrum of what can be done, and that require adapted design strategies. Technosciences deal less with an homogeneous and universal nature, than with a broad range of phuseis that are of local relevance.

Although they invite us to overcome modern concepts and to update perhaps more antique ones, the fact remains that technosciences do not accurately fit in Aristotle metaphysics. Metaphysical concepts such as dispositions are adequate, but

Baird's account of instrumental knowledge concerns science and matters of truth and falsehood, and not technoscience, on which he takes a critical sociological stance (i.e. technoscience means the contamination of the gift economy characteristic of scientific exchanges by the values of market economy). Accordingly, Baird does not go as far as considering a distinctively technoscientific "thing knowledge." Baird's thing knowledge is always about objective knowledge with a pretension to universality, not about local model/objects fittings in which a lot of technoscientific knowledge consists. Similarly Hans-Jörg Rheinberger (1997) defines "experimental systems" as the smallest integral working unit of research where the division between "epistemic thing" and "technical conditions" is relevant. "Epistemic things" are the material entities manipulated in experiments and they embody what researchers do not now or hope to know. When epistemic things become known, they are turned into standard techniques, tools for mundane mapping or commercial applications. They become "technical objects" embodying what has been known during the dialogue between the technical conditions and the epistemic thing. Talking about "technoscientific knowledge" would bypass the distinction between epistemic things and technological conditions that Rheinberger regards as the driver of experimental science. For Rheinberger, it would be talking about industrial development, not about research. 
not for their explanatory power. They matter as agencies operating in the world rather than as causal powers. There is no attempt at identifying basic powers from which everything else could be derived. In stark contrast to laws-centered science, dispositions are introduced for practical reasons, for what they afford. So it is the pragmatist orientation of technoscience, which commands a new ontology.

Technoscientific objects do not fit in Aristotle's metaphysical framework for three additional reasons.

First, many of them (e.g. molecular devices and nanoparticles) are not adequately characterized by a stable structure and constitution as they continuously interact with the instrumental environment. They are better defined as relational entities. In this respect Rom Harré's redefinition of James J. Gibson's concept of affordance is adequate (Harré 2003). The interplay between the experimental setting and the causal powers of the world is the main attribute of affordances. Harré's emphasis on the ontological disparity between the instruments and nature also matters. Together they form a "World/apparatus complex" which conveys the view of the technoscientific world as a domesticated version of the wild world, like a farm, a space of culture.

Second, technoscientific objects such as nanoparticles could hardly be considered as metaphysical substances. In so far as they come into being through the intrinsic dynamic of material entities and endure in existence through interactions they are always in the making, waiting for realization. They challenge the distinction between substantia (what it is) and potentia (what it can do or become). Accordingly, they would rather require the kind of process ontology outlined by John Dupré (2012).

Finally, technoscientific objects challenge the ancient divide between phusis and technè as well as between phusis and nomos. They belong to no specific category and they exhibit multiple temporalities (cosmological, biological, social, technical, economical, ...). From an ontological perspective, they do not appear as coherent entities. A narrative genre like "ontography" seems more appropriate (Loeve and Bensaude Vincent 2017). Unlike ontology, ontography is an attempt to identify the modes of existence of particular entities and focuses on the multiplicity of modes. Not only it deflates the quest for the fundamental level underlying material entities (Lynch 2013) but it does not assume a causal chain between levels of being. In this perspective, technoscientific objects appear as both real and historical. Real because as agencies they interact with the world and its causal powers; historical because they exist thanks to transitory associations of natural powers, technological instruments and people, and like any of us, they have a life trajectory.

\section{Political-ethical profile: Value-ladenness}

Technoscience challenges the classical dichotomy between subjects and objects of knowledge. On the one hand, the transcendental ego gave way to a plurality of heterogeneous producers of knowledge including situated scientists and engineers, instruments, hackers, science policy makers, ... on the other, the objects of knowledge are no longer defined by their relation to the representations of knowing subjects. Rather, they are defined by what they do, by their presence and performance in the world - while epistemic agents are redefined by their participation in the agency of objects. Technoscience thus challenges the classical dichotomy between subjects and objects not only from the viewpoint of knowledge but also from that of ethics. 
Technoscientific objects shift from the modernist self-image of science as value neutral because they are explicitly value-laden, endowed with values that are epistemic as well as economic (e.g. competitiveness), sociopolitical or ethical (e.g. sustainable development). Whereas something comes to existence as a scientific object when it is considered as a matter of fact and kept away from the matters of interests it elicit, technoscientific objects have no clear-cut boundaries that would circumscribe their existence to the realm of pure research versus applications, or of facts versus values, object versus subject, properties versus uses, being versus becoming, etc. Contrary to the alleged neutrality or amorality of scientific research its applications alone being considered value-sensitive - technoscientific objects are designed to acquire new capacities and functions in an ongoing process of valuation. Therefore, they have "unrestricted materiality": what counts as technoscientific object cannot be defined once and for all. As exemplified by carbon allotropes they may change their mode of existence by connecting with different entities (Loeve and Bensaude Vincent 2017). When traveling in different environments like nanoparticles, technoscientific objects shift identity in vivo (Faadel et al. 2013, Albanese et al. 2014). Their materiality may spread far away from what designers initially planned - an issue that is of ethical concern since technoscientific objects may connect to other entities in unpredictable ways.

Technoscientific objects are value-laden not only because they are designed to suit human purposes for useful applications but rather because they are mundane. While they often behave in unfamiliar ways, elicit surprises or display uncanny properties, they are made familiar for lay publics through their merging with wellknown objects such as the "molecular wheelbarrow" and so on (Loeve 2011b). They are invested with a variety of values and interests that make them worldly and talkative, meaningful for everyone. The ethos of disinterestedness, or the epistemological break that Gaston Bachelard described as constitutive of scientific activity, are abolished: Technoscientific objects such as the oncomouse or stem cells are close to the laypublic, they are both attractive and repulsive, they generate hopes and fears. Undoubtedly, the strong involvement of artists in bio- and nanotechnology highly contributed to this trend.

The heavy load of values carried by technoscientific objects is indeed due to the porous boundaries between science and society in what science policy analysts have labeled "Mode 2" research (Gibbons et al. 1994), or "post-normal science" (Funtowicz and Ravetz 1993). However, the load of values far exceeds the expectation of industrial applications or economic benefits. Technoscience is much more than application-oriented research. It is better defined by its axiological charge resulting from a process of investment by multiple actors. The intrinsic value-laden character of technoscientific objects can lead to dignify technoscience (it is not only about money, power and practical efficiency) as much as to critically engage with technoscientific objects (by showing how alternative values could or should be invested in their design). The two stances are not exclusive. All sorts of values epistemic, technological, societal, economic, military, and environmental - are invested in technoscientific research so that, as Javier Echeverria (2003) argues, it is the conflict of values, which characterizes what he describes as the "technoscientific revolution." Technoscientific research consequently demands assessments and regulations that are both matters of concern in the community of philosophers of science. 


\section{Conclusion}

In this chapter, we have made the case for the constitution of a philosophical concept of technoscience despite its polemic charge. As philosophers we are neither pro nor contra technoscience as we have no normative purpose. We do not even claim that technoscience took over science because, in our view, science and technoscience are not stable categories with fixed attributes and boundaries. Rather we consider technoscience as an idealtype of research practice focused on the design of objects which may still co-exist with the scientific idealtype. In labeling objects as "technoscientific" and scrutinizing their epistemological, ontological, and ethical status we hope to open up new philosophical perspectives.

The concept of technoscience is an incentive for philosophers of science to pay more attention to emerging technologies as well as for philosophers of technology and STS scholars to address knowledge issues (Houkes 2009). In this respect, it may act as a boundary concept between current STS and recent philosophical trends concerned with objects, things and modes of existence. While contributing to the "empirical turn" taken by the philosophy of technology (Kroes and Meijers 2001; Brey 2010), a philosophy of technoscience has the potential to open up the field of philosophy to the "political turn" taken by STS scholars in the last decade (Pestre 2004, 2008, 2010), as well as to the ontological twist given to the STS movement by its pioneers Woolgar and Latour (Woolgar and Lezaun 2013; Latour 2013). Finally, a philosophy of technoscience is vital to develop critical views about the cloud of buzzwords, which surround a number of big research projects, and more importantly to better understand what's going on in research laboratories and the kind of objects that come into existence.

\section{References}

Albanese, A., Walkey, C. D., Olsen, J. B., Guo, H., Emili, A., \& Chan, W. C. (2014). Secreted biomolecules alter the biological identity and cellular interactions of nanoparticles. ACS Nano, 8(6), 5515-5526.

Arroyo, M., Heltai, L., Millán, D., \& DeSimone, A. (2012). Reverse engineering the euglenoid movement. Proceedings of the National Academy of Sciences, 109(44), 17874-17879.

Attwater, J., \& Holliger, P. (2014). A synthetic approach to abiogenesis. Nature Methods, 11(5), 495-498.

Baird, D. (2004). Thing knowledge: A philosophy of scientific instruments. Berkeley: University of California Press.

Bensaude Vincent, B. (2001). The construction of a discipline: Materials science in the U.S.A. Historical Studies in the Physical and Biological Sciences, 31(part 2), 223-248.

Bensaude Vincent, B. (2009). Les vertiges de la technoscience. Façonner le monde atome par atome. Paris: La Découverte.

Bensaude Vincent, B. (2016). The moral economy of synthetic biology. In J. Boldt (Ed.), Synthetic biology. Metaphors, worldviews, ethics and law (pp. 87-100). Springer VS: Wiesbaden.

Bensaude Vincent, B., Loeve, S., Nordmann, A., \& Scharz, A. (2011). Matters of interest: The objects of research in science and technoscience. Journal for General Philosophy of Science, $42,365-383$.

Bensaude Vincent, B., Loeve, S., Nordmann, A., \& Schwarz, A. (Eds.). (2017). Research objects in their technological setting. Abingdon: Routledge. 
Brey, P. (2010). Philosophy of technology after the empirical turn. Techné: Research in Philosophy and Technology, 14(1), 36-48.

Bunge, M. (2012). Evaluating philosophies. New York: Springer.

Cachat, E. (2016). Engineering self-organization in mammalian cells, bioarchitecture symposium, In: Living machines, 5th international conference in biomimetic and biohybrid systems, Edinburg, July 19-22, 2016.

Caldwell, L. K., \& Deville, W. B. (1968). A syllabus for the study of science, technology and public policy. Bloomington: Indiana University Press.

Carrier, M., \& Nordmann, A. (Eds.). (2010). Science in the context of application. Boston studies in the philosophy of science (Vol. 274). Dordrecht: Springer.

Cartwright, N. (1999). The dappled world. A study of the boundaries of science. Cambridge, MA: Cambridge University Press.

Chang, H. (2004). Inventing temperature: Measurement and scientific progress. Oxford: Oxford University Press.

Channel, D. F. (2017). A history of technoscience. Erasing the boundaries between science and technology. Abingdon: Routledge.

Chemcal \& Engineering News. (1983). 61 (32).

Clement, R. C. (1965). Last call for birds of prey. Audubon Magazine, 67(1), 37.

Echeverria, J. (2003). La revolucion tecnocientifica. Madrid: Fondo de Cultura Economica.

Elowitz, M. B., \& Leibler, S. (2000). A synthetic oscillatory network of transcriptional regulators. Nature, 403(6767), 335-358.

Endy, D. (2005). Foundations for engineering biology. Nature, 438(7067), 449-453.

Fadeel, B., Feliu, N., Vogt, C., Abdelmonem, A. M., \& Parak, W. J. (2013). Bridge over troubled waters: Understanding the synthetic and biological identities of engineered nanomaterials. Wiley Interdisciplinary Reviews: Nanomedicine and Nanobiotechnology, 5(2), $111-129$.

Forman, P. (2007). The primacy of science in modernity, of technology in postmodernity and of ideology in the history of technology. History and Technology, 23(1/2), 1-152.

Funtowicz, S., \& Ravetz, J. (1993). Science for the post-normal age. Futures, 31(7), 735-755.

Galison, P. (2017). The pyramid and the ring. A physics indifferent to ontology. In B. Bensaude Vincent, S. Loeve, A. Nordmann, \& A. Schwarz (Eds.), Research objects in their technological setting (pp. 15-26). Abingdon: Routledge.

Gelfert, A. (2013). Synthetic biology between technoscience and thing knowledge. Studies in History and Philosophy of Science Part C: Studies in History and Philosophy of Biological and Biomedical Sciences, 44(2), 141-149.

Gibbons, M., Limoges, C., Nowotny, H., Schwartzman, S., Scott, P., \& Trow, M. (1994). The new production of knowledge - the dynamics of science and research in contemporary societies. London: Sage.

Gibson, D. G., et al. (2010). Creation of a bacterial cell controlled by a chemically synthesized genome. Science, 329(5987), 52-56.

Greco, J., \& Groff, R. (Eds.). (2013). Powers and capacities in philosophy: The new Aristotelianism. London: Routledge.

Guchet, X. (2011). Les technosciences: un essai de définition. PhilonSorbonne, 5, 8395. https://philonsorbonne.revues.org/348

Hacking, I. (1983). Representing and intervening. Cambridge, MA: Cambridge University Press.

Haraway, D. (1997).Modest_Witness@Second_Millennium.FemaleMan@Meets_OncoMouse ${ }^{\mathrm{TM}}$ : Feminism and Technoscience. New York: Routledge. 
Haraway, D. (2003). The companion species manifesto : Dogs, people, and significant otherness. Chicago: Prickly Paradigm Press.

Harré, R. (2003). The materiality of instruments in a metaphysics of experiments. In H. Radder (Ed.), The philosophy of scientific experimentation (pp. 19-39). Pittsburgh: Pittsburgh University Press.

Hottois, G. (1979). L'inflation du langage dans la philosophie contemporaine. Bruxelles: éditions de l'Université de Bruxelles.

Hottois, G. (1984). Le signe et la technique. La philosophie à l'épreuve des techniques. Paris: Aubier.

Hottois, G. (1996). Entre symboles et technosciences. Un itinéraire philosophique. Seyssel: Champ Vallon.

Houkes, W. (2009). The nature of technological knowledge. In A. Meijers (Ed.), Philosophy of technology and engineering sciences (pp. 309-350). Amsterdam: Elsevier.

Idhe, D. (1991). Instrumental realism: The interface between philosophy of science and philosophy of technology. Bloomington: Indiana University Press.

Idhe, D., \& Selinger, E. (Eds.). (2003). Chasing technoscience, a state of the art view of technoscience studies featuring the work of Donna Haraway, Don Idhe, Bruno Latour, Andrew Pickering. Bloomington: Indiana University Press.

John, D. (2012). Life as a process. Oxford: Oxford University Press.

Jones, R. A. (2004). Soft machines. Nanotechnology and life. Oxford/New York: Oxford University Press.

Klein, U. (2005). Technoscience avant la lettre. Perspectives on Science, 13(1), 226-266.

Kroes, P., \& Meijers, A. (Eds.). (2001). The empirical turn in the philosophy of technology. Amsterdam: Elsevier.

Lasswell, H. D. (1946). The interrelations of world organization and society. The Yale Law Journal, 55(5), 889-909.

Lasswell, H. D. (1948). The prospects of cooperation in a bipolar world. The University of Chicago Law Review, 15(4), 877-901.

Lasswell, H. D. (1957). The political science of science. Scientific Monthly, 84(1), 34-44.

Latour, B. (1987). Science in action. Milton Keynes: Open University Press.

Latour, B. (2013). An inquiry into modes of existence. Cambridge, MA: Harvard University Press.

Loeve, S. (2011a). Sensible atoms: A techno-aesthetic approach to representation. NanoEthics, 5(2), 203-222.

Loeve, S. (2011b). 'Ceci n'est pas une brouette' Grands et petits récits des nanotechnologies. In O. Thierry \& S. Houdart (Eds.), Humains, non-humains (pp. 208-220). Paris: La Découverte.

Loeve, S., \& Bensaude Vincent, B. (2017). The multiple signatures of carbon. In B. Bensaude Vincent, S. Loeve, A. Nordmann, \& A. Schwarz (Eds.), Research objects in their technological setting (pp. 185-200). Abington: Routledge.

Lynch, M. (2013). Ontography: Investigating the production of things, deflating ontology. Social Studies of Science, 43(3), 444-462.

Lyotard, J.-F. (1979). La condition postmoderne. Paris: Minuit. English Edition: Lyotard, J.-F. (1984). The postmodern condition (G. Bennington \& B. Massumi, Trans.). Minneapolis: University of Minnesota.

Marliere, P. (2009). The farther, the safer: A manifesto for securely navigating synthetic species away from the old living world. Systems and Synthetic Biology, 3(1-4), 77-84. 
Bensaude Vincent, B. \& Loeve, S. (2018). Toward a Philosophy of Technosciences. In Loeve, S. Guchet X., \& Bensaude Vincent B. (eds.), French Philosophy of Technology. Classical Readings and Contemporary Approaches, Cham: Springer, pp. 169-186. Post-print version.

Mazzolai, B. (2014). A robot that grows like plant roots, EU project. https://ec.europa.eu/programmes/horizon2020/en/news/barbara-mazzolai-plantoidproject-robot-grows-plant-roots

Nandagopal, N., \& Elowitz, M. B. (2011). Synthetic biology: Integrated gene circuits. Science, $333,1244-1248$.

Nordmann, A. (2006). Collapse of distance: Epistemic strategies of science and technoscience. Danish Yearbook of Philosophy, 41, 7-34.

Nordmann, A. (2010). Philosophy of technoscience in the regime of vigilance. In G. Hodge, D. Bowman, \& A. Maynard (Eds.), International handbook of regulating nanotechnologies (pp. 25-45). Cheltenham: Edward Elgar.

Nordmann, A., Radder, H., \& Schiemann, G. (Eds.). (2011). Science transformed? Debating claims of an epochal break. Pittsburgh: Pittsburgh University Press.

O'Malley, M. (2009). Making knowledge in synthetic biology: Design meets kludge. Biological Theory, 4(4), 378-389.

O'Malley, M. (2011). Exploration, iterativity and kludging in synthetic biology. Comptes rendus de l'académie des sciences-Chimie, 14(4), 406-412.

Pestre, D. (2003). Regimes of knowledge production in society. Towards a more political and social reading. Minerva, 41, 245-261.

Pestre, D. (2004). Thirty years of science studies: Knowledge, society and the political. History and Technology, 20(4), 351-369.

Pestre, D. (2008). Challenges for the democratic management of technoscience: Governance, participation and the political today. Science as culture, 17(2), 101-119.

Pestre, D. (2010). What about participation, governance and politics? Remarks on contemporary techno-science and the field of STS. In M. Epple \& C. Zittel (Eds.), Science as cultural practice: Vol. I: Cultures and Politics of research from the early modern period to the age of extremes (pp. 163-182). Munich: Akademie Verlag.

Raynaud D. (2015). Note critique sur le mot 'technoscience'. Zilsel. https://zilsel. hypotheses.org/1938

Raynaud, D. (2016). Qu'est ce que la technologie? Paris: Éditions Matériologiques.

Rheinberger, H.-J. (1997). Toward a history of epistemic things. Stanford: Stanford University Press.

Riskin, J. (2015). The restless clock. A history of century-long argument over what make living things tick. Chicago: The University of Chicago Press.

Roherty, J. M. (1960). Oskar Morgenstern, the question of national defense. American Political Science Review, 54(2), 530-531.

Rudd, R. L. (1964). Pesticides and the living landscape. Natural Resources Journal, 4(1), 432 434.

Sebbah, F. D. (2010). Qu'est ce que les technosciences? Une thèse épistémologique ou la fille du diable? Paris: Les Belles Lettres.

Seris, J.-P. (1994). La Technique. Paris: Presses universitaires de France.

Simondon, G. (2005). L'individuation à la lumière des notions de forme et d'information. Paris: Millon.

Simondon, G. (1958). Du Mode d'existence des objets techniques. Paris: Aubier (2013 edition). English edition: Simondon, G. (2016). On the mode of existence of technical objects (C. Malaspina, Trans.). Minneapolis: Univocal Publishing.

USA Today. (2010). Scientists create 1st bacteria strain from man-made DNA. 20/05/2010.

Woolgar, S., \& Lezaun, J. (Eds.). (2013). Special issue: A turn to ontology in science and technology studies? Social Studies of Science, 43(3), 321. 